\title{
Descriptive Analysis of Reasons of Participating Literacy Courses and Effects of Being Literate ${ }^{1}$
}

\author{
Ayhan Erbay*
}

\begin{abstract}
The aim of this study is to find out the effects of literacy acquisition on adults' lives by exploring their background, experiences, and thoughts pertaining literacy's effect. In order to find effects of literacy, qualitative case study method was used and semi-structured interviews were carried with nine participants. It is found that almost all participants had similar life histories, which triggered them to looking for new solutions in order to cope with life. Age and psychological status of participants were especially powerful inputs in participation process. All participants became able to travel, read and write in order to perform in their daily lives without having relied on others after completion of the course. In addition, all participants in this study felt themselves more confident, improve their communication skills and develop sense of empowerment. As a result, it was found that the literacycoursesshould be separated according to the age and psychological status of the participants as well as content of the curriculum.
\end{abstract}

Keywords: Literacy Courses, Effects of Literacy Courses, People Education Centers

\section{Okuma Yazma Kurslarına Katılmanın Nedenleri ve Okur Yazar Olmanın Etkilerinin Betimsel Analizi}

Öz: Bu çalışmanın amacı, okuryazarlık ediminin katılımcıların arka planlarını, deneyimlerini ve düşüncelerini keşfederek yetişkinlerin yaşamları üzerindeki etkilerini bulmaktır. Okur yazarlığın etkilerini bulmak için niteliksel vaka çalışması yöntemi kullanılmış ve dokuz katılımcı ile yarı yapılandırılmış görüşmeler yapılmıştır. Neredeyse tüm katılımcıların, yaşamla başa çıkabilmeleri için yeni çözümler aramaya teşvik eden benzer yaşam öyküleri olduğu bulunmuştur. Katılımcıların yaşı ve psikolojik durumu, katılım sürecinde özellikle güçlü girdilerdir. Tüm katılımcıların okuma yazma kursuna katıldıktan sonra kimseye bağımlı olmaksızın seyahat edebildikleri, günlük aktivitelerini gerçekleştirebilmek için okuyabildikleri ve yazabildikleri ortaya çıkmıştır. Ayrıca, tüm katılımcılar kendilerine daha fazla güvenmeye başladıklarını, iletişim becerilerini gerliştirdiklerini ve güçlenmişhissettiklerini bildirmişlerdir. Sonuç olarak, okuma yazma kursları müfredat içeriğinin yanı sıra katılımcıların yaşlarına ve psikolojik durumlarına göre ayrışması gerektiği bulunmuştur.

Anahtar Sözcükler: Okuma Yazma Kursları, Okuma Yazma Kurslarının Etkileri, Halk Eğitim Merkezleri 
Literacy is an acquisition, which enables people to read and write. It is also widely accepted as a way to acquire the necessary knowledge and skills to express someone's thoughts, to share his/her experiences and to adapt to a community withdynamic structure. In all societies, literacy, its functions, effects and roles are dealt with in different ways. Social and cultural codes may determine what literacy is (Bourdieu and Passeron, 1977) but this also brings complexity in order to reach a global definition of literacy. Holme (2004) claims that everyone has an opinion about what literacy is, however no one can put a clear meaning of it. It seems safe to say that most people who can read or write have a fairly clear idea of what literacy is. Nevertheless, when focusing on any definition of a practice or a state of knowledge, it gets harder to understandwhat they really mean.

With neo-liberal policies, the definition of literacy has been revised and roles of individuals are identified within the terms of economic productionas it is crucial for economic, social and political participation and development, especially in today's knowledge societies (United Nations Educational, Scientific and Cultural Organization [UNESCO], 2006).

Faced with the growing amount of computer based knowledge the definition of literacy has been revised once more. Individuals are given a new broadening role as agents who do not produce knowledge but consumeand disseminate the produced knowledge The Organization for Economic Co-operation and Development [OECD], 2010). Using information, adapting to new technological era, being literate in terms of community development are the key issues and the new purposes of the literacy education. These elements are pre-requisite for activating personal and socioeconomic progression, which is linked with education proces in supranational organizations' definitions of education. However, in the definitions, skills and competencies that are underlined and associated with literacy have ignored individuals' cultural and social background. All forms of personal knowledge, skills, and attitude, has forced to transform into economic capital which is the stock of competences, knowledge and personality attributes embodied in the ability to perform labor so as to produce economic value (Bourdieu, 1983). This re-constructed disposition of educational process also brings out a new pattern, which depends of the markets' needs. So, in the definitions of OECD and UNESCO, education and related sub-field, like literacy, is modified as a premise of improvement of economy.

The term functional literacy is preserved for the level of reading and writing which is a basic requirement in a modern society. In one hand, according to Barton, Ivanic, Appleby, Hodge, and Tusting (2007), functional literacy emphasizes the idea that although people may have basic levels of literacy, they need a different level to function in their daily lives. Therefore, main goal of the functional approach is to "re-produce readers who meet the basic reading requirements of modern society (p.15)". This alteration has led to the development of functional literates, regulated primarily to meet the requirements of more complex technological society (Barton et al., 2007). On the other hand, Freire and Macedo (1987) argue that functional literacy puts emphasis on the automated learning of reading skills while sacrificing the critical analysis of the social and political order that generates the need for reading. Literacy within this perspective is geared to make adults more productive workers and citizens within a given society. As Holme (2004) explains, it is quite common to think about education as being linked to the economic performance of the individual and their society. The emphasis on the knowledge economy in the contemporary capitalist societies created further justification for literacy increasingly tied to economic performance because learning itself is treated as a commodity that can be sold or exchanged for goods. It means such societies invest in its population in order to make them more skilled and productive individuals or a commodity rather than independent human being who have their own choices and lives.

Instead of defining literacy from an economic point of view, critical approachhave emphasized the social and political context of literacy, taking into account the socio-cultural forms of development and the concerns of different communities and individuals. Literacy is seen as contributing to social transformation and empoweringpeople to participate actively in the democratic process (Stromquist, 2006a). The goal is, basically, to overcome oppression (Freire, 1972). Contrary to the Functionalist Approach, the Critical Approach focuses on the individual and the strength of the individual to transform the community. Literacy training is seen as 
a fundamental instrument that individuals who could not be educated for various reasons use to participate in society.

Critical approach relates literacy with developing a critical consciousness and skills that an individual is starting to interrogate the current social, economic, politic conditions. Freire (1972) emphasizes the importance of bringing the learner's socio-cultural realities into the learning process itself and then using the learning process to challenge these social processes. According to Freire's pedagogy reading is a process of interpreting, reflecting on, interrogating, theorizing, investigating, exploring, probing and questioning whilewriting isan acting on and dialogically transforming movement (Oxenham, 2008). Freire and Macedo (1987) state that literacy can only be emancipatory and critical to the extent that it is conducted in the language of the people. So, participators use their own native language to define the world and start to link with powerful class in order to transform communal and governmental structures.

In spite of the outcomes, which are uncovered by the studies mentioned above, illiteracy is still a major concern for many countries. According to UNESCO statistics (2017), the global literacy rate is $86 \%$ among adults who are over 15 years old. Comparingly, approximately 750 million people are illiterate whom $63 \%$ of them are women among adults who are over 15 years old.

As seen from Table 1, according to the Turkish Statistic Institution [TUIK, 2018] about 2,5 million adults which is $3,2 \%$ of the country are illiterate. Moreover, percentage of illiterate people who participated in literacy course is very low, around $5 \%$, but drop rates are very high as $35 \%$ for last four years. So, there should be important assumptions as to why adults do not participate in literacy courses. Low self-confidence, negative attitudes toward education, financial and communicational barriers, time constraints, family responsibility and lack of familiarity with the courses, fear and hesitation regarding the environment, dissatisfaction with education are some of these among Turkish population (Çankaya, 2005; Kirazoğlu, 1996; Yıldız, 2006).

However, Nohl and Sayılan (2004) emphasized that the methodology of literacy teaching and the purpose of the institution that teaches literacy is an important matter affecting participation rate. Teaching reading, writing, and numeracy in a style that promotes freedom and in a transformative approach will be different from a style which does not promote critical thinking. The state power isin the position that affects adults' ability of self-esteem, critical thinking, civic rights or skills of reading hospital signs, calculate shopping lists, within the aims and applications of literacy education. The state itself, as a system, is the focal point of all dynamics reveals the disadvantageous situation of the adult illiterates because ofthe problem of illiteracy and economic and political imbalance. Providing a well balanced literacy education; aims of literacy education, type of the content that will be used, the methodology of the literacy training, the target groups of literacy training, and which languages to be taught must be taken into account while preparing an adult literacy program.

Table I

Literacy Courses and Participation Rates in Turkey (included municipalities' and Non Governmental Organizations' programs)*

\begin{tabular}{cccccc}
\hline Years & $\begin{array}{c}\text { Number of } \\
\text { Illiterate People }\end{array}$ & $\begin{array}{c}\text { Number of } \\
\text { Literacy Courses }\end{array}$ & $\begin{array}{c}\text { Number of } \\
\text { Participators }\end{array}$ & $\begin{array}{c}\text { Number of } \\
\text { Graduated } \\
\text { Participators }\end{array}$ & $\begin{array}{c}\text { Percentage of } \\
\text { Reached People } \\
\text { Course Drop Out }\end{array}$ \\
\hline 2016 & 2.462 .604 & 10.369 & 79.461 & 34.315 & 3,23 \\
2015 & 2.583 .951 & 20.522 & 162.781 & 90.693 & 6,3 \\
2014 & 2.583 .951 & 15.317 & 134.527 & 80.193 & 5,21 \\
2013 & 2.540 .527 & 18.808 & 179.050 & 175.433 & 4,29 \\
\hline
\end{tabular}

${ }^{*}$ General Directorate of Public Education, Ministry of National Education, Turkey

\section{Literacy Education in Turkey}

Ministry of National Education [MONE] is the main literacy education provider in Turkey. According to MONE statistics (MONE, 2018) there are over 10.000 literacy courses have been offered and almost 80.000 people participated in the courses in 2016. MONE has also authorized municipalities and some nongovernmental institions (e.g. Mother Child Education Foundation (Anne Çocuk Eğitimi Vakfı [AÇEV]) and Rotary Club) to offer literacy courses throughout the country. 
Adult literacy education courses provide in two levels by MONE in Public Education Centers. The first level of literacy courses lasts 90 hours with the purposes of teaching writing skill, numeracy skills and basic civic education, using Turkish language effectively, and training participants on some skills and behaviors, which are related to daily life. After 90 hours course program, participants will get a final exam. If participants pass, the exam they will get basic literacy certificate and they can apply the second level of literacy courses. Second level of literacy courses has a length of 180 hours. Participants who arecomplete successfully the whole process awarded a certificate which is equal to primary school diploma (MONE, 2009).

MONE (2007) states the purposes of the adult literacy courses for illiterate people as to generate functional literacy skills in order to develop personal, social, and economic progress and provide necessary skills for participating in global socio-cultural conditions. Furthermore, MONE puts forward an acquisition list, for adult learners, which cover critical understanding, creative thoughts thinking, searching, decision-making, reasoning, using information technology, self-discipline, participation, collaboration, solidarity, using Turkish language effectively and efficiently, etc.

MONE's adult literacy courses are subject of some criticism. Nohl and Sayllan (2004) notes that Level 1 Literacy courses of MONE aimed to teach basic literacy, numeracy and civic education emphasizes the duties of a good citizen rather than teaching people their human rights and ways of using these rights. Their analysis of the instructional materials and methods revealed that in these courses literacy was reduced to a technical skill taught with a behaviorist approach. The instructional materials, which were based upon elementary school subjects, should be re-designed to take the needs and life experiences of adult learners into consideration. They also criticizes the materials for reinforcing traditional gender roles of women and asked for in-service training on the principles of adult education for elementary school teachers teaching these courses.

There are also literacy programs offered by non-governmental organizations in Turkey. Functional Adult Literacy Courses is offered by AÇEV. They focus on participants' experiences, while they learn how to read and write. There are some deficiencies in their textbooks like democracy, human rights, and gender equality (Toprak, 2017). Despite those deficiencies, AÇEV's program creates fundamental standing for empowering women (Nohl and Sayllan, 2004). Simplified Reading and Writing Education Program is being organised by the Rotary Club in Turkey. Their teaching method starts with a collective activity (e.g. cooking) and then they define each action while they cooking with separated sentences. The fundamental aim of this program is to use participants' experiences and view to create sentences and texts (Nohl and Sayllan, 2004). From the early time of the Turkish Republic, literacy courses and campaigns had played an important role on the rise of literacy rate of the population. Primary education was made compulsory in 1924 with the primary teaching and education law number 222. In addition to this, literacy courses for illiterate adultswas begun in 1924, and five literacy campaigns were launched for a wide range of people in the years of 1928, 1960, 1971, 1981, and 2001 (Kirazoğlu, 2003).

This study aims to analyze how literacy courses affect participants' lives from the viewpoint of the participants. No matter what the definition of literacy, it is obvious that individuals who lack the skills and competencies given in the educational settings suffer in their daily lives. It is important to determine how and what way literacy courses affect individuals. Moreover, it is crucial to find out how literacy courses and individuals affect each other in terms of the improvement of individual competencies and course processes. In order to find the effects of adult literacy education programs, interview questions are categorized into two groups: i) what is the participation process of adults in literacy courses included their life stories and memories? and ii) how does adult literacy education affect the lives of participants?

\section{Method}

This study examines how adult literacy education affects participants, using qualitative inquiry for the research questions it aims to answer. It uses descriptive case study method. In this part research method and process are explained, participants, data collection and analysis procedures are defined. 


\section{Research Method}

Descriptive case study has used as a research method in order to describe how literacy course affects participants' lives in their real life context from their perspectives.

\section{Sample}

Convenience sampling was used to select research participants. Five participants were from the first level and four were from the second level of literacy courses at People's Education Centers in İstanbul Europe zone. All participants were female. The ages of participants ranged from sixteen to sixty-two years (four of them were below twenty-five; five of them were above fifty years old). Participants were born and grew up in different cities of Turkey and moved to Istanbul due to various reasons like economic deprevation, being close to their children, etc.). Four of the participants were married and three of them have children. Two of them work as clerks, two of them are looking for a job actively, and five of them have never worked and they do not attempt to find one. While seven of participants had never gone to school, two of them had dropped out from primary school (5th and 3rd grade) due to their families' suppressions. Four of them have maintained their extended family; five of them were transformed into nuclear family after migration.

\section{Data Collection and Research Ethics}

A semi structured interview form was developed according to the research questions of this study. Yazlık's study (2008) and Nohl and Sayılan's reports (2004) about adult literacy education in Turkey were also helpful in formulating interview questions. The interview form was revised after the pilot study which held in another MONE's Public Education Center in İstanbul.

There are three categories in interview questions. The first category is about the participants' background information (e.g. their life history, their economic and social background, their demographic information like age, gender, marital status, etc.) which deals with developing profiles and comparing participants' experiences and thoughts in order to understand their motivation to participate in literacy courses. The second category is about exploring the participation process, like how they decided to participate in literacy courses, what was their family's reaction, etc. The last category is related with the effects of literacy in participants' lives.

The researcher explained the purpose, objectives, interview method, general characteristics of variales, and duration of the interviews to the trainees who participated in the study in line with scientific ethical principles. Participants were informed that they would not make any profit by participating in this study, they could withdraw from the research at any point during the interview, and their identities would remain confidential. All participants have signed informed consent form.

\section{Data Analysis}

The researcher recorded all interviews with the informed consent of the participant and fully transcribed the interviews. The interviews were content analyzed to identify recurring themes and core meanings (Patton, 2002). Each interview was taken as an individual case, with with-in case and cross case analyses (Merriam 1998). Themes were identified by combining the most frequently repeated expressions and examples through descriptive analysis. The researcher first put the answers given to the questions into a list of words, grouped the most frequently repeated expressions, identified the keywords and combined them with examples from the participants' own lives.

\section{Findings and Results}

Findings were divided under two thematic categories. The first category is participation process of adult literacy education, which is consisting of age, gender discrimination, altruism, anger, lack of school or school age problems, psychological well-being, acquiring new skills, and getting a diploma. The second category is effects of literacy course on participants' lives, which is consisting of self-confidence and empowerment, and improved communication skills. 


\section{Age}

The age of participants is an important determinator in both expectations from the literacy course and the reasons for participating. The age of participants in this study can be divided into two categories. The first category is older participants who ranged from 50 to 62 years old. Second group is younger participants who ranged from 16 to 24 years old. Each group has their own unique dynamics in terms of motives behind their participation decisions.

The older group suffered from psychological issues resulting from isolation in new places after migration and negative memories when they asked help from strangers related with literacy skills in their daily lives. They believe that the literacy course may provide an environment where they may be relieved by meeting others who are like them and looking to learn basic literacy skills in order to cope with daily life. Almost no older participants could obtain formal education because of a lack of school or patriarchal power structures where they lived during their childhood. When a school was built, their age became a problem for starting primary education.

\footnotetext{
Participant H (62 Years Old, Female): I was just doing housework after we moved to Istanbul. I never went to a cinema or a tea garden by myself. I got sick two years ago and doctors said that it was not physical but psychological. They said that I should go out and get new friends. One of my neighbors talked about people's education center and invited me to go there with her. I came here once and I observed all women doing something fun like painting, carpet weaving, learning how to write and read, etc. I decided to participate in painting and literacy courses. I felt good and stronger now.
}

The younger group, on the other hand, expected to find a job after getting their diploma. Participants from this group had a very positive attitude toward their current position and they believed that they can improve their life conditions after graduation from literacy courses. Some of them were working as a clerk in restaurants and other participants were looking for a job. Both groups believed that literacy courses had impacts on their lives such as increased self-esteem and better communication skills before their participation in literacy courses. Participant M (16 Years Old, Female): “I am still young and I thought that I can continue my education until at least high school level. When I get my high school diploma, I can apply for governmental jobs."

\section{Gender Discrimination}

Almost all participants believed that if they were a boy, their families would allow them to start to primary school. According to their opinions, the conservative or patriarchial power structure of the society is the main reason behind their illiteracy. Some of them have expressed their wish to go to school to their family, however they have been ignored. I found it interesting when participants in the sample spoke out their mothers' role in their discrimination. Three of the participants blamed their mother directly because they said that if their mothers provided protection from patriarchal power they could go to school.

Participant R (50 Years Old, Female): My father was a naïve person. He had not any education background. He only followed oral culture and the traditions. He believed that if girls learned howto write, they would write a love letter to boys, and this would be a humiliation for the family.

Participant Z (56 Years Old, Female): I begged my father to send me to school along with the other children in the village. However, he did not listen to me. He told me once, "Girls should not go to school; they should help their family in fields and housework; they should take care of their siblings, if they have any.".

\section{Alturism}

Altruism is another common theme for almost all adults' participation process in theliteracy course. Two common issues need to be considered about alturism. Firstly, participants whose reasons of not being able to go to school due to their altruistic choices are the first or second child in their family. Secondly, altruism emerges among those participants as contributing to their family economically, like working in the fields as a workforce. Participants, who talked about their own altruism (seven out of nine participants), believed that someone had to do duties in the family. There are roles for men andwomen shaped by social and cultural rules.

Participant R (50 Years Old, Female): I was the second child in the family. I had an older brother and two little siblings who were students in primary school. My older brother and I could not find achance to go to school. There was an oral 
agreement between my older brother andme. I was taking care of my mother who was sick since my childhood; and my older brother worked with my father in order to increase income level of the family.

Participant Z (56 Years Old, Female): I could not go to school. There was no school in our village, so all children went to school in the nearest village. My parents did not want to send me to school because I had to work in fields and do housework.

\title{
Anger
}

Some of the participants also mentioned their anger toward their families. The interesting fact is that all participants who are angry with their mothers not the fathers. The reason of the emergence of their anger is about the passive attitudes of mothers where they did not protect or help their daughters in theschooling process.

Participant $\mathrm{R}$ (50 Years Old, Female): I have a great vengeance to my mother. I was passive during my entire life because of her attitudes and thoughts about me. She was against my enrollment in the school and participation in carpet weaving courses. She turned me into a brindled animal. I could never protect my rights, explain myself, and do anything by myself. All of these happened because of mymother.

Participant S (18 Years Old, Female): Sometimes I asked myself what my fault was. If there is a God, I want to ask him where his justice is. My mother is sick, our economic conditions are awful, I sacrificed myself in order to assist my family, and I could not go to school. I could not even play in playgrounds when I was a child. I believe all problems are related with my mother. Those problems that I faced with would not have happened if my mother had been healthy. I had lost my hope for a better life. I was lost myself and wanted my mother die. Can you image that a child wanted her mother die. I felt terrible.

\section{Lack of School or School Age Problem}

All of the participants older than 50 years of age have the same experience. Therewas no school in their village and when the school was established in the village, their age had exceeded the school age when school was established, so they were not accepted to the school.

Participant Z (56 Years Old, Female): There was no school in our village, so all children went to school in the nearestvillage. When a school was established in our village, I wanted to go to school. My father allowed me to go to school. However, my age was bigger than the other newstarters and school principal refused to accept me.

\section{Psychological Well-Being}

Psychological well being is the most important reason in participation to literacy courses in the sample of this study. No matter what the ages of adults, everyone inthe sample felt relief in the courses with having to know others who had similar experiences. Each person in the sample expresses her/himself in the group and learnshow to cope with problems in daily routine in the light of group's thoughts anddirections. All participants in this study have a sort of psychological damage related to their schooling experiences in their childhood, and their adulthood experiences due to their illiteracy. It may be considered that the participants' psychological well-being has improved in terms of their self-confidence and that the literacy courses functionas a rehabilitation process.

\begin{abstract}
Participant R (50 Years Old, Female): When my husband beat me because of my illiteracy, I used to wish I would die rather than be humiliated. My husband has beaten me since we got married. I got married when I was 17 years old. My husband was a civil engineer and he used to beat me because of my ignorance. I was like brindled animal; I could not protect my rights. After I joined literacy courses, I turned into a panther to protect my zone. No one can violate my rights, no one can beat me anymore, and no one can humiliate me. I can read bus plates, I can dial the phone numbers, and I can do anything on my own. All of these make me feel better. I am a complete human now, may be a super human.
\end{abstract}

Participant H (62 Years Old, Female): I came here once and I observed all women doing something fun likepainting, carpet weaving, learning how to write and read, etc. I decided toparticipate in painting and literacy courses. I feel good now and my doctor even reduced my drug dosage.

Secondly, the participants who have traumatic backgrounds in their childhood andadulthood have found a space to express their feelings in literacy courses and they have met with others who have similar backgrounds with them. At this point, theliteracy courses turn into some kind of rehabilitation group in which people who have similar histories share their experiences and realize that they are not alone. This process may be considered as another factor affecting the participants' well-being positively. Participant E (23 Years Old, 
Female): When I started to the literacy course I felt better, I found new friends who have different backgrounds, and I can talk about my problems. It is kind of psychological rehabilitation.

\section{Acquring New Skills}

The most common expectation from the literacy courses is to get new skills in orderto deal with daily life activities on their own. All participants had a negative memory about reading bus plate, dialing phone numbers, filling a document, and getting an appointment from a hospital. They all asked someone for help and they all believed that asking help to read bus plate is a kind of humiliation for them.

Participant H (62 Years Old, Female): I think I can express myself better than before. I know what I am talking and what I am referring. I know numbers so I can get my appointment from thehospital by myself and I can find where the doctors' offices are in the hospitals. Finally, I feel complete. I do not need any help while I am doing something.

\section{Getting Diploma}

Getting a diploma is an expectation related to the ages of the participants. The younger ones see the diploma as a step that leads safer environment in the future by having a desirable job. They believe that if they get a higher degree as much as possible they will be paid better in jobs. All of younger participants in this study stated to continue their education until they graduated from high school level. The older participants, on the other hand, have stated that they would not continue because of their ages. Literacy courses for older participants have served as a space for relaxation, sharing, and learning environment. Younger participants in the sample of this study have conceptualized the purpose of literacy education as a necessary skill to perform well in economic production as functionalist view of literacy education has suggested. Participant S (18 Years Old, Female): After I get my diploma, I am going to apply for a certificate which is important for waiters in order to work in five star restaurants. Moreover, I want to get a driver's license.

Participant M (16 Years Old, Female): If I were a literate person, I am sure that I would find another job easily. Sometimes, I want to resign from this restaurant but I am afraid that I can not find another one. So, I have to be patient. When I get my diploma I am going to search better jobs.

\section{Self-Confidence and Empowerment}

All of the participants stated that their emotions about the problems in their daily life started to change in a more confident, decisive and less hesitant way. As for thechange in relations with their family members, participants had became more proactive compared to their past and they became more optimistic about their future. Increasing self-confidence level has brought on social participation, economic contribution, and psychological well being. Participant R(50 Years Old, Female): "When I fill a document by myself or get an appointment from a hospital, I felt that I can handle with whatever I need to do. I feel that my self-confidence increases."

Participant Z (56 Years Old, Female): I feel I am changing. During the literacy course, I force myself to produce examples related to our study texts. If I produce plenty of them, I feel stronger. I can express myself better than before I attended literacy course. I have better communication with my children and relatives. I learned to listen them and they learned to listen what I am saying. I feel happier.

\section{Improved Communication Skills}

The participants believe that their communication skills have improved when they were able to read since they have learned how to use a word and make a sentence. They also developed their interpersonal communication skills when on break during the course periods. Therefore, older participants especially became much more talkative and started to produce their own ideas about an issue in the family. Participant Z (56 Years Old, Female): "I can express myself better than before I attended literacy course. I have a better communication with my children and relatives. I learn to listen andthey have learned to listen what I said."

\section{Discussion and Suggestions}

There are similarities and differences between this study's findings and other preliminary studies. Yazlik (2008), Yıldız (2006), and Kalkan (1996) have found increasing self-confidence, empowerment and improving 
communication skills to be the effects of adult literacy courses. This study has found similar results in terms of effects of adult literacy education. Previous studies, on the other hand, did not focuson participation process of adults, which is a very important input for understanding the effectiveness of adult literacy courses. This study has found that age, psychological status, past experiences, and altruism were common point of participants.

The age of participants plays a crucial role in adult literacy education in morethan one way. Reasons of participation, effects of courses, and perception of the self during the course process were affected by participant's age. Older participants tended to acquire basic survival skills, which allow them to operate daily activities by their own. On the other hand, younger participants of literacy courses tended to shape their future by getting diploma and finding an appropriate job. As a result, reasons of participation change between older and younger adults in terms of time notion where the older group focuses on present and the younger group focuses on future time in order to improve their life conditions.

Gender discrimination is the most significant obstacle that stands in front of women in accessing school. Being from six different regions of Turkey, women from different age groups and different ethnic backgrounds are all victims due to their gender. Women's statement that they could go to school if they were born as a man proves gender discrimination. It is an interesting finding that women who participated in this study indicated that the most important figure in the process of discrimination was their mother. The reason behind this argument is that their mother would not protect them against dominant social power. Even though the patriarchal society takes its power from men, there can be an explanation of women's not blaming men but women for their subjection to discrimination. Children are born into an existing social structure which protected by various mechanisms. Internalized rules, statuquos, acceptences and responsibilities are turned to unquestionable and unchallenged facts. This is the point where the reason of women's blaiming their mothers. The thought, authority and position of father are never questioned hence the anger is directed to secondary power, to mother. Since mother/woman is easily criticized, it seems inevitable to be the anger directed subject. Education or any other personal transformative tool cannot undermine this structure.

Another important factor in participants' life stories and in process of participation is altruism. Altruism is an important theme for this study because it becomes a coping mechanism while they were not allowed to go to school. By doing so, they could cope with their disappointment and they somehow protect their inner balance pertaining schooling experiences in their childhood. Participants, who talked about altruism, were the first or second children of the family. It may mean that to be the first or second child in the family in a village requires a higher level of responsibility, will of accomplishing the duties, and loyalty to the family. Young participants in the sample have underlined that the only way to get the acceptance of the family and society that they live was through self-sacrifice. Sending boys out for earning money and forcing girls stay at home doing housework tells us that social dynamics form expectations with respect to gender roles. What children need to do is to obey and fulfill their duties. If these duties demand, devotion and children are taught to be proud of this dedication.

All of the participants felt well psychologically. Especially older adults after they migrated to Istanbul, they stated that they had been isolated, their travelling possibilities had been limited, and they faced difficulties in accessing health institutions and that all of these had consumed them psychologically. There are two underlying variables in the relief of participants' psychology. The first one is adults who have similar life stories listen to each other as if they constitute a share group. In this scenario, people who have been subjected to domination and negativity realize that they are not alone when they hear similar stories. When they share their stories, they relieve. On the other hand, the younger participants start to look their life more positively since they feel that they can pursue their education and find a job after graduating the literacy program and getting a diploma. The most significant and concrete asset of literacy programs for the younger participants acquires diploma or certificate. The percieved importance of diploma is related to the organic bond between diploma and working life. This perception very much in line with the neoliberal globalization has attributed function of education, which is about making illiterate adults into literate ones in order to include them ineconomic production and keep them under control. Neoliberal policies' reorganization of educational 
services in parallel to expectations of market and vitalizing the competition in educational systems, lead individuals to desire an endless qualification. An illiterate person faces many difficulties in approving him/herself as a respectable persona and s/he finds mainly jobs that demand bodily efforts. There are some studies about the relation between politic action and adult literacy education program. According to Stromquist (2006b) self-esteem can be considered a personal condition that occurs before social and political action. Accessing to public sphere decision-making appears to requite personal attributes that permit the individual to develop feelings that one can influence one's environment this implies a combination of sense of personal efficacy and self-esteem in the psychological sense. However, distinction between Stromquist (2006b)'s assessment of empowerment and result of this study is about adults' participation on public sphere. Stromquist says that adults who have self-confidence show themselves in political participation in society. In this study, however, adults have become more visible in either economic participation by finding a job or they become more visible in the family relation by improving communication skills.

Critical approach to literacy is related to developing critical consciousness and skills that an individual is starting to interrogate the current social, economic, politic conditions. Oxenham (2008) conceptualized reading as interpreting, reflectingon, interrogating, theorizing, investigating, exploring, probing and questioning; writing, on the other hand, is formulated as acting on and dialogically transforming. According to participants of this study, reading and writing conceptualized as basic skills to perform independently in society. Participants did not mention skills expected to emerge as critical approach stated. However, people may be affected by social dynamics in different levels even if she/he oppressed. People may have different priorities than interpreting the world or starting to ask questions abouther/his conditions. People may choose to survive. Although life stories of the participants of this study are similar, there is a clear distinction between them. They were not sharing same psycho-social dynamics. Every person has one's own unique conditions and affected by society in a different level. The common point for them isto survive in order to read bus tables or finding appropriate doctor in health service. So, the participants of this study have pointed out their personal dynamics which are affected on expectations from literacy course that critical approach does not mentioned. However, changes which emerged in the participants lives (i.e. increased self-confidence, being empowered, and improved communication skills) may support what critical approach conceptualized literacy. Effects of literacy education can establish a link between an adult who became conscience about her/his conditions or environment and society he or she lived in. On the other hand, there was a clear link between reasons of participation to literacy courses and aims of adult literacy education defined by functional approach. According to functional approach the aim of literacy is to enable, people engage in all activities inwhich literacy is required for effective functioning of his/her group and community (UNESCO, 2006). The aims of the participants of this study were getting a diplomain order to apply or find a job, learning to read bus tables in order to travel or to find appropriate health services in hospitals, and learning to write in order to fill adocument to operate bank services.

The effectiveness of literacy courses, concentrated on two points. The first one is about self-confidence and empowerment. The participants of this study believed that their self-confidence was gradually increasing while they actively participated in literacy courses. So, being literate is the way of being exist in the society for them especially considering their past humiliations, ignorance, and shamed related to their literacy skills. To participate in literacy courses may bring respect, support, and acceptance to participants. The second one is about gaining better communications skills while interacting with others. The participants have trained in using Turkish language in literacy courses in either orally or literary. However, even if they become familiar with words and they learn how to use the words in their daily lives, they aimed at using Turkish language in a basic level.

On the contrary, of the related literature, there is no clear link between political effects of literacy courses. Instead, it is found that participants consciously stay away from politics and they did not make a connection between literacy skills and politics. It means Turkish adult literacy education programs reflect functionalist view ofliteracy as UNESCO or OECD defined which focuses on the very basic writing and reading skills of 
illiterate adults. On the other hand, similar social effectsof literacy courses, which are mentioned in, related literature chapter has been found. Increasing self-confidence, empowerment, and improved communication skills are the similar themes. Again, there is not a clear connection between effect of literacy courses and personal economic improvement of participant; however, it may effect on finding a job or improving job status of the participants along with certifications. To conclude, it seems that Public Education Centers should provide psychological services for any participants of any course, especially those who participate in literacy courses. Psychologically supported individuals will feel more powerful in both adaptation of literacy and in coping with their own life problems. Therefore, it would be an important point in turning the literacy programs into a space in which grown ups express and transform them. The most important point should be taken into consideration is that the literacy programs should be designed with respect to age groups since the effects of and the expectations from the courses are different between the age groups. Hence, it would be easy to focus on participants' needs and their personal development would be more fast and accurate as well. Moreover, MONE should design adult literacy education programs according to andragogy rather than pedagogy. Adults are trained with primary school textbooks and methods. This brought lower participation in class activities and increases drop-out level. The majority of the participants of literacy courses indicate the lack of school in the village they live in. This is one of the main reasons of their illiteracy. It seems that most of them would have gone to school if they had a school to attend. It is of vital to raise the number of schools in the rural areas.

There are some limitations about this study. First, this study conducted in Istanbul European zone. It may provide different themes when other cities include the study. Second, number of participators shorthened due to time constraints.

\section{Declarations}

Acknowledgements: The researcher would like to thank the trainees of Kadiköy Public Education Center and the administrative staff of the center.

Authors' contributions: Not applicable.

Competing interests: The researcher does not have any conflicts of interest with any person or institution due to the study.

Funding: The researcher has conducted the study without any financial support from any institution / institution.

\section{References}

Barton D., R. Ivanic, Y. Appleby, R. Hodge, and K. Tusting (2007). Literacy, lives, and learning. London: Routledge.

Bourdieu, P. (1983). The forms of capital (R. Nice, Trans.). Greenword Press.

Bourdieu, P. \& Passeron J.C. (1977). Reproduction in education, society and culture. London: Sage Publications.

Çankaya, D. (2005). Migrant adults' reasons for non-participation in organized adult education activities (Unpublished masters thesis). Boğaziçi University, İstanbul.

Freire, P. (1972). Cultural action for freedom. Middlesex England: Penguin Books.

Freire, P. \& Macedo, D. (1987). Literacy: Reading the word and the world. New York: Routledge \& Keagan Paul

Holme, R. (2004). Literacy: An introduction. Edinburgh: Edinburgh University Press.

Kalkan, B.Ö. (1996). Women participation in people's education centers in İstanbul (Unpublished master thesis). Boğaziçi University, İstanbul.

Kirazoğlu, C. (2003). An evaluation of adult literacy campaigns in Turkey (Unpublished doctoral dissertation). Boğaziçi University, İstanbul. 
Merriam, B.S. (1998). Qualitative research and case study applications in education. San Francisco: Josey-Bass Publishers.

Ministry of National Education (2007). Yetişkin eğitimi ve öğretimi el kitabı. Ankara. Retrieved from: https://www.meb.gov.tr/earged/earged/Yetiskin_Egitimi.pdf

Ministry of National Education (2009). Yearbook of Turkish National Statistics. Ankara. Retrieved from: http://sgb.meb.gov.tr/www/resmi-istatistikler/icerik/64

Ministry of National Education (2018). National education statistics. Ankara. Retrieved from: http://sgb.meb.gov.tr/meb_iys_dosyalar/2019_09/30102730_meb_istatistikleri_orgun_egitim_2018_2019.p $\mathrm{df}$

Nohl, A. M. \& Sayllan, F. (2004). Adult literacy education in Turkey: Support to elementary education project technical report. Ministry of Education/European Commission. Retrieved from: https://www.hsuhh.de/systpaed/wpcontent/uploads/sites/755/2017/12/Teaching-Adult-Literacy-inTurkey.doc

Oxenham, J. (2008). Effective literacy programs: Options for policy makers. Paris: UNESCO. Retrieved from: http://unesdoc.unesco.org/ images/0016/001636/163607e.pdf

Patton, M. Q. (2002). Qualitative research and evaluation methods (3rd ed.). Thousand Oaks, CA: Sage.

Stromquist, N. P. (2006a). Women's rights to adult education as a means to citizenship. International Journal of Educational Development, 26(2), 140-152. doi:10.1016/j.ijedudev.2005.07.021.

Stromquist, N. P. (2006b). The political benefits of adult literacy. UNESCO. Retrieved from: http://citeseerx.ist.psu.edu/viewdoc/download?doi=10.1.1.560.7430\&rep=rep1\&type=pdf

The Organization for Economic Co-operation and Development (2010). How technology changes demands for human skills. OECD Education Working Paper. No. 45. Retrieved from https://www.oecdilibrary.org/docserver/5kmhds6czqzqen.pdf?expires=1540212202\&id=id\&accname=guest\&checksum=2C A0F191BF829D45F764C2FE9E332E52

Toprak, Z. (2017). The discourse of early childhood education and fashioning of modern mothers. Journal of Early Childhood Studies, 1(1), 71-80. doi: 10.24130/eccd-jecs.196720171122.

Turkish Statistical Institute (2018). Ulusal okuma yazma istatistikleri. Retrieved from: https://biruni.tuik.gov.tr/medas/?kn=130\&locale=tr

United Nations Educational, Scientific and Cultural Organization (2006). EFA global monitoring. Paris: UNESCO. Retrieved from: unesdoc.unesco.org/images/0014/001416/141639e.pdf

United Nations Educational, Scientific and Cultural Organization (2017). Literacy rates continue to rise from one generation to the next. Fact Sheet No.45. Retrieved from:

http://uis.unesco.org/sites/default/files/documents/fs45-literacy-rates-continue-rise-generation-to-nexten-2017_0.pdf

Yazlık, Ö. (2008). The effect of people education centers' literacy courses on women lives (Unpublished master thesis). Boğaziçi University, İstanbul.

Yıldız, A. (2006). Adult literacy in Turkey. A critical approach to adult literacy education (Unpublished doctoral dissertation). Ankara University, Ankara. 